\title{
Interactive Whiteboards in the Living Room? - Asking Children about their Technologies
}

\author{
Matthew Horton \\ University of Central Lancashire \\ Preston \\ PR1 2HE \\ +44(0)1772 895151 \\ mplhorton@uclan.ac.uk
}

\author{
Janet C Read \\ University of Central Lancashire \\ Preston \\ PR1 2HE \\ +44 (0) 1772893285 \\ jcread@uclan.ac.uk
}

\begin{abstract}
In this poster we report the findings from a study of technologies in the home and school and use these results to discuss the validity and variability of children's reports of technologies.

The results indicate that children may not understand well the types of interactive technologies that were discussed and that there may be some confusion about the names of technologies. In addition, the study indicated some confusion about where a technology resides.
\end{abstract}

\section{Categories and Subject Descriptors}

H.1.2 [Models and Principles]: User/Machine Systems human factors;

\section{General Terms}

Measurement, Design, Human Factors.

\section{Keywords}

Children, Surveys, Technology

\section{INTRODUCTION}

Asking children about technology is a technique used by both designers and evaluators of many different kinds of products. It is mainly used by designers to see what level of exposure children of different ages have had to technologies (either general or specific) which can be useful is determining the level of sophistication in a product. Evaluators use experience surveys slightly differently to find out children's prior use of technology is. This prior use could have a significant impact on how the child uses or interacts with a product during an evaluation session. For research studies, knowledge of prior experience is often essential to ensure a balanced design.

This paper looks at one popular method of eliciting this information from children and discusses some of the validity issues of the data that is collected using this method.

\section{TRADITIONAL METHODS}

There are many different methods used in eliciting information from children, the most common of which include

(C) The Author 2008 .

Published by the British Computer Society questionnaires, interviews, brainstorming and think-aloud.

Questionnaires are primarily used as they can be completed by a large amount of people simultaneously without the need for the creator / owner to be present. Whilst they do allow for large amounts of data to be gathered, the quality of this data is questionable due to the owner not knowing exactly why an answer has been chosen.

With children, there is a particular risk of satisficing (choosing a good enough answer [1] and so to overcome this, special methods, like the Fun Toolkit [3], are sometimes applied.

Interviews are one of the best methods of gathering information as they allow the administrator to deviate from the questions they have to ask in order to get exactly the information they require. They do however bring in the possibility of administrator bias as it is easier to lead a person, especially a child, to answer a certain way. In addition, interviewing children can be very stressful as children do not well understand the question- answer process. [2]

Brainstorming and think-aloud are similar methods, both designed to gather large amounts of information from groups of people. These methods have been found to be less stressful or 'scary' for children as they are more comfortable working in groups with their peers. It does however lead to the quieter children being left out if the administrator is not able to engage them.

When eliciting information from users it is always best to use more than one method for example brainstorming may come up with ideas that due to the design of a questionnaire or interview would never appear.

\section{THE STUDY}

This research was carried out in a local primary school using two classes from different Key Stage (KS) levels of the National Curriculum. 23 children aged 6 and 7 from a year 2 (KS1) class and 20 children aged 9 and 10 from a year 5 (KS2) class.

All children within the class were given the option to take part in the study and the children were told they could stop participating in the research at any time.

The children were given a written questionnaire made up of two questions. The first asked the children to indicate which of a list of technologies the had at home, the second asked the same question but this related to school. The choices of technologies were presented to them in a two columned list and the children were asked to tick the boxes against the items they had. 
To reduce 'copying' the two questions were presented on different sides of the questionnaire.

\section{RESULTS}

The results from the questionnaires were entered into a spreadsheet to be analyzed by the researchers. Table 1 shows a condensed version of the results with the number being the number of children who said that a specific technology was present either in their home or at their school. Group 1 is the year 2 (KS1) children and group 2 in the year $5(\mathrm{KS} 2)$ children.

Table 1. Questionnaire Results

\begin{tabular}{|c|c|c|c|c|}
\cline { 2 - 5 } \multicolumn{1}{c|}{} & \multicolumn{2}{c|}{ Group 1 } & \multicolumn{2}{c|}{ Group 2 } \\
\cline { 2 - 5 } \multicolumn{1}{c|}{} & Home & School & Home & School \\
\hline Mobile Phone & 20 & 20 & 18 & 1 \\
\hline Laptop & 16 & 22 & 9 & 19 \\
\hline Games Console & 11 & 7 & 19 & 16 \\
\hline Photocopier & 11 & 17 & 4 & 18 \\
\hline Video Camera & 15 & 14 & 12 & 15 \\
\hline Video Recorder & 13 & 1 & 12 & 8 \\
\hline DVD Player & 22 & 5 & 18 & 14 \\
\hline Printer/Copier/Scanner & 3 & 2 & 7 & 6 \\
\hline Home Telephone & 16 & 19 & 17 & 19 \\
\hline Computer (PC) & 14 & 12 & 12 & 19 \\
\hline Handheld Console & 11 & 0 & 17 & 4 \\
\hline Printer & 13 & 18 & 9 & 17 \\
\hline Interactive Whiteboard & 6 & 20 & 2 & 19 \\
\hline Television & 21 & 17 & 18 & 18 \\
\hline Digital Camera & 14 & 10 & 16 & 18 \\
\hline
\end{tabular}

\section{DISCUSSION}

Here we discuss some of the interesting results that can be seen from the table above. Whilst both questions provided us with interesting data, the technology in the school question does allow us to do a comparison between the two groups as all the children attended the same school.

\subsection{Technologies in the home}

Without talking to parents or visiting each child's house we cannot say whether the data gathered is totally accurate, however, from the results we can make a few assumptions that lead us to the conclusion that this information is not $100 \%$ accurate.

Certain items within the technology list were added as they can be found in the majority of primary schools in the UK. These items are less likely to be found in the home (although we acknowledge that it is possible). 8 of the children reported to having interactive whiteboards within their homes and 15 of the children reported having photocopiers - notably, most of these reports came from the younger children..

There are three possibilities that could explain these reports; the first is that the child misunderstood the question - maybe couldn't read the words, the second is that the child 'thinks' that he or she has this item in the home but really hasn't got it, the third is that the item does indeed exist in the home. To discover which of these explanations fit, we will need to further question the children to ascertain exactly what prompted this answer. We might need to ask what they consider to be these devices and what they understand by the terms such as 'interactive whiteboard' as they may, for example, have a whiteboard notice board at home that looks similar to the whiteboard they have at school but has no interactivity at all.

Further to this 2 of the children reported to having every piece of technology at home (they ticked every box) which could be due to this being true, but could also be put down to them 'wanting to look good' or possibly not taking the questionnaire seriously. It was noted that these children did not tick every box for the question their school.

\subsection{Technologies at school}

The comparison between the two groups has provided some interesting results to question the validity of this style of questionnaire.

If the questionnaire had just been completed by group 1 then we would assume that the children have access to mobile phones at school as $87 \%$ of the children said they have these at school. However only $5 \%$ of the children in group 2 answered the same way. Therefore if this questionnaire had only been done with 1 group we would have had completely differing results for this question.

A lot of questions did however receive similar results across the two groups leading us to believe that these results are accurate; it is only a few technologies where results differ significantly.

Listening to the children talk whilst completing the questionnaires brought up an interesting question. What exactly does 'at school' mean. Children said that teachers have their mobile phones at work. Whilst these are not for school use, they are in school and have clearly been seen by the children. Also the after school club at the school has a games console but after speaking to the teachers the school does not. Whilst the after school club takes place on the school property it is run by a different organization and uses it's own equipment.

\section{FURTHER WORK}

The data gathered for this poster is part of a larger piece of research looking into different methods of administering questionnaires to children. The data from this questionnaire will be compared with the data from a pictorial version of the same questionnaire that was carried out with the same children several weeks prior to this written questionnaire.

\section{ACKNOWLEDGMENTS}

Our thanks to the children and teachers of English Martyrs Primary School for their participation in this research.

\section{REFERENCES}

[1] Borgers, N. and Hox, J. "Item Non response in Questionnaire Research with Children.” Journal of Official Statistics, 2001, 17(2): 321 - 335.

[2] Borgers, N., J. Hox and Sikkel, D. "Response Effects in Surveys on Children and Adolescents: The Effect of Number of Response Options, Negative Wording, and Neutral Mid-Point." Quality and Quantity, 2004, 38(1): $17-33$.

[3] Read, J. C., S. J. MacFarlane and Casey, C. Endurability, Engagement and Expectations: Measuring Children's Fun. Interaction Design and Children, Eindhoven, Shaker Publishing, 2002 